Id en line Revista de Psicologia. Ano 2, No. 4, Fevereiro de 2008 - ISSN 1981-1179.

\title{
Cotidiano
}

\section{SOMBRA E LUZ}

José Emerson Monteiro Lacerda (1)

A China preserva uma tradição milenar, vistas as técnicas de registro que desenvolveu como nenhuma outra civilização. A propósito, lembre-se que fabricou o papel, aperfeiçoou a porcelana e a seda, além de produzir instrumentos de orientação, depois utilizados pelos ocidentais quando de suas viagens para conhecer o resto do mundo.

Dentre consagrados gênios do pensamento chinês, a figura de Fo-Hi, o Imperador Amarelo, se ressalta pelas pesquisas no campo da Ciência Universal. Sábio consciencioso, voltou-se para o ser humano em sua busca de adaptação com a natureza. E dos conhecimentos que legou à posteridade um aqui avaliamos: o Princípio Único da Bipolaridade, isto é, tudo tem de ter o seu contrário para poder existir. Ou Yin/Yang, a Lei Universal da matéria, base de todo progresso tecnológico.

Sobre este assunto alguma coisa mais pode ser falada, o que faremos em seguida: Após passarem a existir, sem que se avalie disto o mérito, seres animados e inanimados se vêem submetidos ao equilíbrio desses dois extremos, o centrífugo e o centrípeto. $\mathrm{Na}$ energia elétrica, são os dois pólos, negativo e positivo, a terra e a fase.

Caso analisados sob o prima dialético, fenômenos e objetos se apresentam dentro da obediência deste princípio. Lua e Sol. Noite e dia. Açúcar e sal. Mulher e homem. Escuro e claro. Frio e quente. Esquerdo e direito. Tudo pressupõe seu outro lado, possibilitando correlação comparativa e complementar na outra extremidade. Friedrich Hegel demonstrou essa Lei, na Filosofia, quando referendou seu método, de tese e antítese a gerar uma síntese e início de nova tese, aspectos distintos do processo dialético em movimento constante. 
Id en line Revista de Psicologia. Ano 2, No. 4, Fevereiro de 2008 - ISSN 1981-1179.

\section{Setas espirituais}

As religiões também utilizam de referências idênticas, desde a mais remota delas, registrada em livro, o Hinduísmo, onde se lê na Sublime Canção dos Vedas (Bhagavad Gita) um diálogo entre Arjuna, guerreiro em conflito quanto a lutar ou se omitir face a batalha extrema. E Krishna, a Suprema Personalidade de Deus, que the indica o caminho da Verdade, mantendo seu ânimo de lutar. Depois, veio o Budismo, com os frutos da evolução individual de Gautama, que despertara em si o Eu Búdico, ou o Buda (Iluminado), no outro lado de si mesmo, o Eu Superior.

No Cristianismo, Jesus de Nazaré, após os quarenta dias no deserto, virá às margens do rio Jordão, no Batismo, dividir a História com o advento do Cristo (Ungido de Deus), sua outra natureza, seu Lado Interior, transformação que passa a demonstrar durante as andanças persistentes que realizada em seu messianato, através das cidades palestinas, anunciando o Reino Divino que habita o coração de cada ser humano - Sois deuses e não o sabeis.

Meu caminho é o do coração. Ninguém chegará ao Pai a não ser por mim. Buscai a porta estreita, porque larga é a da perdição. Não saiba a vossa mão esquerda o que dá a vossa direita. Se vosso olho é mau, todo o vosso corpo é mau. Se vosso olho é bom, todo o vosso corpo é bom. Brilhe a vossa luz.

A mesma lei veio também orientar a moderna Psicologia, uma vez que o mesmo princípio perpassa todas as coisas do Universo, segundo afirma Hermes Trismegisto, sábio do Antigo Egito. No âmbito da pesquisa psicológica atual, os resultados denotam que a essência da personalidade compreende uma harmonia que se perfaz no funcionamento proporcional das engrenagens do Ego e do Eu Superior, mesmos valores até aqui abordados.

\section{Os hemisférios}

Distantes dos conceitos apenas abstratos, ver-se na composição física do corpo, em sua arquitetura, que o cérebro se estrutura em dois hemisférios, esquerdo e direito, a se 
Id en line Revista de Psicologia. Ano 2, No. 4, Fevereiro de 2008 - ISSN 1981-1179.

entrecruzarem nas ramificações nervosas para com o restante dos órgãos, a coordenar lados internos e externos contrários, o Sistema Nervoso Central, enquanto que se comunicam por estreita faixa denominada corpo caloso - uma ponte correspondente a $25 \%$ de toda a área fronteiriça desses dois territórios, qual traço de ligação.

Estudos de funcionalidade avaliam que existe uma proporção de predominância na razão de 1 para 3 , de um lado sobre o outro, as mesmas equivalências de terra e água, na face do planeta Terra.

Como visto, o mesmo princípio também percorre tudo o mais que existe, e ao se saber que um dos aspectos possui luz própria, no contexto da própria Lei, sem que sejam necessários juízos de valor, numa inferência se conclui que a Verdade existe, independente das opções individuais das criaturas, qual coisa em si sobranceira às perscrutações e idiossincrasias das escolhas particulares.

A luz do Sol é própria; a da Lua, refletida.

$\mathrm{Na}$ energia elétrica, apenas o positivo dispõe da fase, ou fogo, com mostra a experiência cotidiana; o outro pólo, a terra, poderá ser isolado até a exteriorização da força, como se dá nos sistemas de fornecimento que utilizam apenas um cabo para eletrificação, exemplo adotado como alternativa de menores custos.

Nesta seqüência de raciocínio, a lógica reflete uma norma original, aonde o progresso se evidencia qual declividade sutil, as águas correm sempre para o mar, no dizer do povo. As trevas fogem da luz, porém a luz não foge das trevas. E o Homem se vê na condição inalienável de um dia ser feliz, pelo triunfo definitivo do Amor sobre o Ódio.

No entanto, isso compete ao livre-arbítrio de cada serciente, que deve evoluir por esforço exclusivo, sendo-lhe franco o plantio de uma inevitável colheita, como propõem inúmeras filosofias e religiões: A cada um conforme o seu merecimento.

\section{A travessia}

Devemos daí mudar de lado, romper o cristal que nos divide, guindados pelo poder maior da Consciência, e passar ao outro hemisfério cerebral, que também somos nós. Para percorrer este caminho de libertação, atravessa-se o Mar Vermelho da matéria, na seiva 
Id en line Revista de Psicologia. Ano 2, No. 4, Fevereiro de 2008 - ISSN 1981-1179.

colorida que nos irriga vasos, veias e artérias, para chegar na Terra da Promissão e viver o sonho da real felicidade. Eis o mito hebreu da Pessash, ou Páscoa, a significar Travessia, da escravidão para a liberdade.

Quando Saulo de Tasso, na estrada de Damasco, se refazia do impacto vivido na presença da Luz, se depara com tamanha mudança interior, passa a ser conhecido por Paulo, e afirma: - Não sou eu quem vive. É o Cristo que vive em mim.

Portanto, a capacidade humana de se auto-avaliar demonstra conteúdo espontâneo de um fenômeno biológico permanente, em cumprimento de trilhas originais e concatenadas entre si, quais percurso da Terra em volta de um eixo imaginário, iluminandose ao Sol que a clareia do Leste para o Oeste. Do olho esquerdo para o direito - na rotação própria da evolução - quando cada olho corresponde a um hemisfério de predominância abstrata, no espaço físico do Cérebro.

Certa feita, afirmaram que somos tais dois castelos, um junto do outro. O castelo da Ilusão e o da Ciência. E que entre eles existe uma única diferença, a saber: Do castelo da Ilusão não se vê o da Ciência, mas do da Ciência se vê o da Ilusão.

A história de Jesus bem claro patenteia este enfoque como a fonte do Poder Atemporal, revestindo de mistério simples de sentir e viver, desfazendo bloqueios à percepção definitiva daquilo que nos acompanha pelos dias vividos. Fundaram até, em proveito de pompas e privilégios, os conceitos indeclináveis de secreto, tabu, mágico, milagroso, dentre outros, sempre em detrimento da maioria e a favor de uma elite prestigiosa e impenitente, por mais sabedoras dos estudos reunidos pela cultura oficial. Com a democracia das oportunidades, veio a secularização das idéias, ora em ebulição no seio da espécie. Recordamos, desse tempo, a invenção da imprensa, que deu publicidade à herança letrada, propiciando a vulgarização de textos antes retidos a sete chaves, para beneficiar grupos de poder.

(1) José Emerson Monteiro Lacerda é Advogado e Escritor E-mail: emersomonteiro@gmail.com. 